\title{
Trace element intake by Asians during pregnancy
}

\section{By Rachel Abraham, Northwick Park Hospital, Watford Road, Harrow, Middlesex}

In Harrow, we have a community of Asians who originate from Gujarat-a state in north-west India. A study was set up to investigate the trace metal status in this group of Asian vegetarians and non-vegetarians and in a white control group, because the increased demands of pregnancy could precipitate a deficiency in women with marginally adequate diets. The trace element study is part of a much larger study looking at the general nutritional status, perinatal morbidity, etc., within the above mentioned population in Harrow. The established role of trace metals in animal reproduction increases the likelihood of the existence of such an association in humans.

The vegetarian diet, high in both phytates and fibre which binds available zinc, creates the potential for marginal $\mathrm{Zn}$ deficiency. In addition, foods eaten by vegetarians tend primarily to be poor sources of $\mathrm{Zn}$. There is little information in the literature on the trace metal intake of Asians in Britain and we felt it necessary to try and establish whether the diets of the Asians in Harrow were poor, marginal or adequate with regard to $\mathrm{Zn}$ and copper.

\section{Procedures used in the investigation}

A $7 \mathrm{~d}$ dietary recall was done on 100 unselected Asians and 50 European controls at the booking visit to the ante-natal clinic. The latter were selected by the last digit of the hospital number. The diets of the Asians were checked again at 28 and $34-36$ weeks. Assessment was based on standard household measures including bowls used by the Gujaratis. The intake results were then analysed using a computer.

Inadequate data on the $\mathrm{Cu}$ and $\mathrm{Zn}$ content of certain Asian foods eaten by this group, made laboratory analysis necessary.

\section{Results and discussion}

The following are preliminary results of twenty vegetarian and twenty non-vegetarian Asians and twenty European controls (see Tables I and 2).

For the mean intake of a group, the recall method is reasonably accurate. A week is the minimal reliable unit of time for dietary assessment because the meal patterns at the weekend differed from those of the weekdays in this group However, the diets of the Gujaratis of Harrow are monotonous, which makes assessment more straightforward.

Trace metals $(\mathrm{Zn}$ and $\mathrm{Cu}$ ). Differences between $\mathrm{Zn}$ intakes in the vegetarian and non-vegetarian and controls groups were significant $(P<0.00 \mathrm{I})$. The $\mathrm{Zn}$ intake of the controls were similar to the estimate of II $16 \mathrm{mg}$ (Davies, 1977) from food 
Table I. Intakes of zinc, iron and copper in vegetarian, non-vegetarian and control subjects

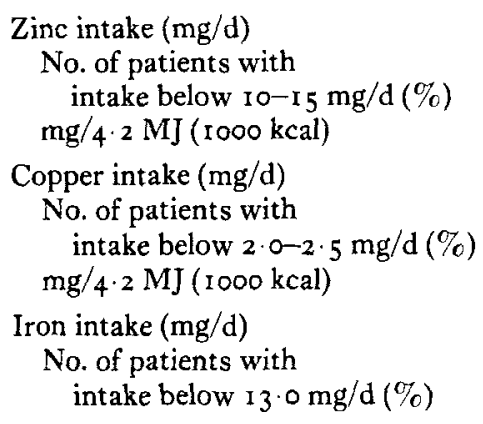

\begin{tabular}{|c|c|c|c|c|c|}
\hline \multicolumn{2}{|c|}{$\begin{array}{l}\text { Vegetarian } \\
(n 20)\end{array}$} & \multicolumn{2}{|c|}{$\begin{array}{l}\text { Non-vegetarian } \\
\left(\begin{array}{l}n \text { 20) } \\
\end{array}\right.\end{array}$} & \multicolumn{2}{|c|}{$\begin{array}{l}\text { Control } \\
(n 20)\end{array}$} \\
\hline Mean & SEM & Mean & SEM & Mean & SEM \\
\hline $7 \cdot 35$ & $0.4^{2}$ & $10 \cdot 2$ & 0.55 & II 5 & 0.49 \\
\hline \multicolumn{2}{|c|}{$19(95)$} & \multicolumn{2}{|c|}{$9(45)$} & \multicolumn{2}{|c|}{$5(25)$} \\
\hline $3 \cdot 5$ & 0.1 & $4 \cdot 7$ & 0.2 & $6 \cdot 2$ & 0.2 \\
\hline$I \cdot 3^{8}$ & 0.07 & I. 93 & 0.25 & $I \cdot 7^{2}$ & 0.20 \\
\hline \multicolumn{2}{|c|}{ I9 (95) } & \multicolumn{2}{|c|}{ I $5(75)$} & \multicolumn{2}{|c|}{ I $7(85)$} \\
\hline 0.67 & 0.02 & 0.91 & 0.13 & $0.9^{2}$ & 0.09 \\
\hline II $\cdot 2$ & 0.54 & I $2 \cdot 8$ & $0 \cdot 7^{6}$ & II 0 & 0.54 \\
\hline \multicolumn{2}{|c|}{$16(80)$} & \multicolumn{2}{|c|}{$9(45)$} & \multicolumn{2}{|c|}{$14(70)$} \\
\hline
\end{tabular}

Table 2. Intakes of energy, protein, fibre, vitamin $B_{12}$, vitamin $D$ and phytic acid in vegetarian, non-vegetarian and control subjects

\begin{tabular}{|c|c|c|c|c|c|c|}
\hline & \multicolumn{2}{|c|}{$\begin{array}{l}\text { Vegetarian } \\
\left(\begin{array}{l}n \text { 20) } \\
\end{array}\right.\end{array}$} & \multicolumn{2}{|c|}{$\begin{array}{l}\text { Non-vegetarian } \\
\quad\left(\begin{array}{l}n \text { 20 })\end{array}\right.\end{array}$} & \multicolumn{2}{|c|}{$\begin{array}{l}\text { Control } \\
(n 20)\end{array}$} \\
\hline & Mean & SEM & Mean & SEM & Mean & SEM \\
\hline $\begin{array}{l}\text { Energy intake }(\mathrm{MJ} / \mathrm{d}) \\
\text { No. of patients with intake }\end{array}$ & $8 \cdot 70$ & 0.47 & $9 \cdot I$ & 0.4 & 775 & 0.26 \\
\hline below I0.0 MJ $(2400 \mathrm{kcal})(\%)$ & \multicolumn{2}{|c|}{ II (55) } & \multicolumn{2}{|c|}{$7(35)$} & \multicolumn{2}{|c|}{$17(85)$} \\
\hline $\begin{array}{l}\text { Protein intake }(\mathrm{g} / \mathrm{d}) \\
\text { No. of patients with intake } \\
\text { below } 60 \mathrm{~g} / \mathrm{d}(\%)\end{array}$ & $57 \cdot 0$ & $3 \cdot 4$ & $73 \cdot 5$ & $4 \cdot 3$ & $81 \cdot 5$ & $3 \cdot 1$ \\
\hline Dietary fibre $(\mathrm{g} / \mathrm{d})$ & $23 \cdot 0$ & $I \cdot 4 I$ & $22 \cdot 6$ & I 4 I & $16 \cdot 4$ & $1 \cdot 20$ \\
\hline $\begin{array}{l}\text { Vitamin } B_{12} \text { intake }(\mu \mathrm{g} / \mathrm{d}) \\
\text { No. of patients with intake } \\
\text { below } 3-4 \mu \mathrm{g} / \mathrm{d}(\%)\end{array}$ & $20(100)$ & 0.16 & $7 \cdot 80$ & 2.19 & $9 \cdot 30$ & I. 74 \\
\hline $\begin{array}{l}\text { Vitamin D intake }(\mu \mathrm{g} / \mathrm{d} \\
\text { No. of patients with intake } \\
\text { below } 10.0 \mu \mathrm{g} / \mathrm{d}(\%)\end{array}$ & 0.85 & 0.14 & $1 \cdot 70$ & $0 \cdot 30$ & $2 \cdot 35$ & $\begin{array}{l}0.3^{6} \\
\text { o) }\end{array}$ \\
\hline Phytic acid intake (g/d) & 0.80 & 0.07 & $0 \cdot 75$ & 0.04 & 0.40 & 0.07 \\
\hline $\begin{array}{l}\text { Phytate: zinc molar ratio } \\
\text { No. of patients with phytate: } \mathrm{Zn} \\
\text { molar ratio I0.0 or above }(\%)\end{array}$ & 10.5 & 0.6 & $7 \cdot 5$ & 0.5 & $3 \cdot 5$ & 0.6 \\
\hline
\end{tabular}

consumption patterns from the National Food Survey of 1976 (National Food Survey Committee, 1978) and they fit in with the Department of Health and Social Security (1969) estimates of $10.0-15.0 \mathrm{mg} / \mathrm{d}$. However, it is higher than the $9 \cdot$ I $\mathrm{mg} / \mathrm{d}$ reported by Spring et al. (1979). Analysis done at the National Institute of Nutrition, Hyderabad, (1978) on different regional diets has shown that the intake of $\mathrm{Zn}$ in Gujarat is $7 \cdot 6-9.3 \mathrm{mg} / \mathrm{d}$ which is consistent with our results. 
The ratio of $6.2 \mathrm{mg} \mathrm{Zn/4.2} \mathrm{MJ}$ (rooo kcal) among the control group was much higher than that of $0.95 \mathrm{mg} / \mathrm{MJ}(3.97 \mathrm{mg} / 4.2 \mathrm{MJ}$ (1000 kcal) reported by Spring et al. (1979)). It is at the upper limit of the range of $2 \cdot 7-6 \cdot 3 \mathrm{mg} / 4 \cdot 2 \mathrm{MJ}$ (1000 kcal) quoted by Holden et al. ( I979) who assessed the diets of twenty-two men and women. This is probably due to the higher protein:energy value that we see in our control group.

Analysis of the regional diets of India indicates that the average intake of $\mathrm{Cu}$ in Gujarat is $\mathbf{I} \cdot 6-2 \cdot \mathbf{I m g} / \mathrm{d}$ which is very similar to the intakes of $\mathrm{I} \cdot 3^{8}$ and I. $93 \mathrm{mg} / \mathrm{d}$ in the vegetarians and non-vegetarians respectively.

Spring et al. (1979) report a mean intake of $\mathrm{Cu}$ in the UK of $\mathrm{I} .5 \mathrm{mg} / \mathrm{d}$ in average sized families (which is how we would classify the European controls) with a supplement of $0.3 \mathrm{mg}$ from alcohol, chocolate and water. This would be similar to the intake of our controls. Mean intakes of $\mathrm{Cu}$ are reduced to I.53 \pm 0. I I and $1 \cdot 37 \pm 0.06 \mathrm{mg} / \mathrm{d}$ in non-vegetarians and controls respectively when those who consume liver are excluded. A large proportion falls below the figures quoted by the Department of Health and Social Security ( 1969 ) which may suggest that those values are an overestimation.

Trace element concentrations have been determined on hair, plasma and urine, of patients in this study, though results are not included in this paper.

Iron and calcium. Intakes of $\mathrm{Fe}$ were similar in all three groups though a significant proportion of $\mathrm{Fe}$ in the Asian diet was from vegetables and cereals. Excluding those who eat liver, results in a reduction in the $\mathrm{Fe}$ intake of controls to $9.9 \pm 0.53$, but does not significantly alter that of the non-vegetarians. The intake of Fe does not include medicinal Fe which is prescribed for all patients attending Northwick Park Hospital ante-natal clinics.

The intake of Ca was $1280 \pm 92,1200 \pm 89$ and $1090 \pm 98 \mathrm{mg} / \mathrm{d}$ in the vegetarian, non-vegetarian and control groups, respectively and on the average, about half the patients in each group received less than $\mathrm{I} 200 \mathrm{mg} / \mathrm{d}$. Thus, the mean intakes of $\mathrm{Ca}$ were marginally inadequate in all three groups in relation to the recommended value.

Energy and protein. The European control group belongs to a high social class, eats a high-protein, low-energy diet and consequently has a mean energy intake below those reported recently in Aberdeen of $8.8 \mathrm{MJ}(2090 \mathrm{kcal})$ and $8.4 \mathrm{MJ}$ $(2013 \mathrm{kcal}) / \mathrm{d}$ for the two groups investigated (Campbell et al. 1982). All the mean energy intakes were well below the recommended daily intake but this may not imply undernutrition. Intakes of protein were significantly different $(P<0.001)$ between the vegetarians and non-vegetarians or European controls. In a sample, we have data on $24 \mathrm{~h}$ urine analysis and there was a similar difference between the urea:creatinine values of vegetarians and controls, an added confirmation of the method of dietary assessment.

Vitamins $B_{12}$ and $D$. Dietary intake of vitamin $\mathrm{B}_{12}$ varies with the amount of animal products consumed. The vegetarians, not surprisingly, had a mean intake below the average intake of vitamin $B_{12}$ in the UK. The amount of vitamin $B_{12}$ in the diets of non-vegetarians and controls dropped to $2.94 \pm 0.32$ and 
$5.13 \pm 0.47 \mu \mathrm{g} / \mathrm{d}$ respectively when intakes of those who consume liver were excluded. National average intakes quoted by Spring et al. (r979) are slightly less than that of our controls. All intakes are below $10.0 \mu \mathrm{g} / \mathrm{d}$. The Asians are routinely supplemented at Northwick Park Hospital, with ro.o $\mu \mathrm{g}$ vitamin D/d.

\section{Phytic acid and dietary fibre}

Dietary fibre and phytate occur together in foods and there is some uncertainty about the relative binding effect on $\mathrm{Zn}$ of these two constituents.

Phytate is considered to bind $\mathrm{Zn}$ and thus the intakes of phytic acid may be of importance. The differences reported here were not as marked as those of $\mathrm{S}$. Warrington (unpublished results) who observed values of $1 \cdot 14 \pm 0.97 \mathrm{mg}$ for Asian adults and $0.45 \pm 0.64 \mathrm{mg}$ for Europeans. Phytic acid intakes in the controls were reduced by $50 \%$ to $0.20 \pm 0.03$ when those eating wholemeal products were excluded.

An expression of dietary $\mathrm{Zn}$ adequacy is the phytate: $\mathrm{Zn}$ molar ratio. Differences here are significant $(P<0.00 \mathrm{I})$ but not many non-vegetarians are above the at risk value of 10 mentioned by Oberleas $\&$ Prasad (1976).

The fibre intakes of the controls were lower than the intake of $19 \cdot 9 \pm 5.3 \mathrm{~g} / \mathrm{d}$ recorded of sixty-three men and women in the Cambridgeshire village (Bingham et al. 1979 ) and $19.7 \mathrm{~g} / \mathrm{d}$ of the 1976 National Food Survey. The intake of dietary fibre was $14.4 \pm \mathrm{I} \cdot 54 \mathrm{~g} / \mathrm{d}$ in the controls when those who eat wholemeal products are excluded. Differences between the intakes of dietary fibre of the Asians and the controls were significant $(P<0.001)$.

\section{Concluding remarks}

The intakes of twenty vegetarians, twenty non-vegetarians and twenty European controls were assessed by a $7 \mathrm{~d}$ dietary recall. $\mathrm{Cu}$ levels in all groups were well below those quoted by the Department of Health and Social Security (1969) and $\mathrm{Zn}$ intakes were substantially lower in the vegetarian than non-vegetarian. Phytic acid and dietary fibre intakes were higher among the Asians than the controls. Using the Department of Health and Social Security (1969) average daily intakes of $\mathrm{Zn}$ and the recommended daily intake of energy for pregnancy, the $\mathrm{Zn}$ :energy value of $4 \cdot 16-6 \cdot 25 \mathrm{mg} \mathrm{Zn} / 4 \cdot 2 \mathrm{MJ}$ (1000 kcal) suggests that the nutrient density of $\mathrm{Zn}$ in the diets of the Asian non-vegetarian and the control is good.

$0.83-\mathrm{I} .04 \mathrm{mg} \mathrm{Cu} / 4.2 \mathrm{MJ}$ (1000 kcal), which is met by diets of the Asian non-vegetarian and the controls when the diet includes liver. However, the vegetarian diets have high phytate: $\mathrm{Zn}$ ratios and do not fall within the above mentioned ranges of metallo:energy values. The availability of these trace elements in the diet of the vegetarians is considerably less than in the diets of non-vegetarians and controls, and this could lead to a nutritional deficiency of $\mathrm{Zn}$ or $\mathrm{Cu}$. 


\section{REFERENCES}

Bingham, S., Cummings, J. H. \& McNeil, N. I. (1979). Am. J. clin. Nutr. 32, 1313.

Campbell, D. M., Campbell-Brown, B. M. \& Jandial, L. (1982). Proc. Nutr. Soc. 41, 3oA.

Davies, N. T. ( 1977). In Child Nutrition and Its Relation to Mental and Physical Development, p. 2 I. Manchester: Kellogg Company of Great Britain.

Department of Health and Social Security. (1969). Recommended Intakes of Nutrients for United Kingdom. Dept. Publ. Hlth Med. Subj. No. 120. London: HM Stationery Office.

Holden, J. M., Wolf, W. R. \& Mertz, W. (1979). F. Am. Diet. Ass. 75, 23.

National Food Survey Committee (1978). Household Food Consumption and Expenditure. 1976. London: HM Stationery Office.

National Institute of Nutrition ( I 978). Annual Report. Jamai-Osmania P.O. Hyderabad, India.

Oberleas, D. \& Prasad, A. S. (1976). In Trace Elements in Human Health and Disease, vol. I, p. $5^{8}$ [A. S. Prasad, editor]. London: Academic Press Inc.

Spring, J. A., Robertson, J. \& Buss, D. H. (I 979). Br. F. Nutr. 41, 487 . 